\title{
RADIOLOGICAL-CLINICAL ASPECTS CYSTICERCOSIS
}

\author{
Rade R. Babić1 , Gordana Stanković-Babić2,4, Marko Ristić ${ }^{3}$
}

\begin{abstract}
Cysticercosis (cysticercosis) represents a disease caused by cellulose cysticercus (Cysticercus cellulosae), a larva of the pork tapeworm (Taenia solium), when a man is a transient host. The aim of the study is to present the radiological-clinical aspects of cysticercosis (cysticercosis). The study illustrates the radiological findings and pictures of cysticercosis in one female patient, brought as a refugee to Niš by the hurricane of war in Bosnia and Herzegovina, via a concentration camp and with the mediation of UNPROFOR. The authors conclude that the radiographic image of cysticercosis is typical, that radiological examination methods are relevant in the diagnosis of cysticercosis, while the diagnosis with certainty can be established on the basis of clinical picture, radiological images, serological results and epidemiological data.
\end{abstract}

Acta Medica Medianae 2017;56(4):90-93.

Key words: cysticercosis, radiology, microbiology, veterinary medicine

\footnotetext{
${ }^{1}$ Radiology Center, Clinical Center Niš, Serbia

2Ophthalmology Clinic, Clinical Center Niš, Serbia

${ }^{3}$ Veterinary Institute Subotica, Subotica, Serbia

${ }^{4}$ University of Niš, Faculty of Medicine, Niš, Serbia

Contact: Rade R. Babić

Bul.dr Zorana Đinđića br. 48, 18000 Niš, Serbia

E-mail: gordanasb@mts.rs
}

pigs. Better cooperation is required between the sanitary and veterinary services in combatting pork cysticercosis and human taeniasis.

Taeniasis (teniosis) is a disease caused by the parasites of the genus Taenia, beef tapeworm ( $\mathrm{T}$. saginata) or pork tapeworm ( $T$. solium), present in the small intestine of the host $(1,2,3,7,13)$.

\section{Clinical-microbiological considerations of cysticercosis}

Pork tapeworm (Taenia solium) is 2-8 m long. On it, head, neck and body can be differentiated. The head (scolex) is of spherical appearance, with a diameter of approximately $1 \mathrm{~mm}$, which has the beak (rostellum), with two rows of hooks, 20-30 in number and four suckers. The neck (collum) is thin and long and continues into the body (strobila). The body consists of 800 to 1.000 segments (proglottides), unequal in maturity and size, which at the beginning of the chain are immature, wide and short, and at the end of the chain are mature, long and narrow. The last segments have eggs, up to 50,000 , round or oval in shape, measuring around 30-45 microns. Within the fertilised egg is an embryo, hexacanth, with three pairs of chitin hooks (stylets). Mature segments detach from the stem and travel to the external environment via fecal mass. The eggs may be released even in the instestines of the host. The eggs in the external environment, if the conditions are favourable, may survive about two months. When a pig eats the eggs of tenia, the eggs release the embryo in its small intestine, which penetrates the bowel wall, and then through blood or lymph is transported to various organs, most commonly the neck muscles and other ske- 
letal muscles, tongue, heart, brain, eye and elsewhere. At the site of settlement the embryo loses stylets and turns into a larva of the vesicular type (Cysticercus cellulosae), known as a measle. The size of a measle is about $10 \mathrm{~mm}$. It is transparent, filled with clear liquid, round, although its shape depends on the tissue within which it develops, with the time of life of about 3-6 years, the longest being in the eye of about 20 years, and after death it calcifies.

The development cycle of parasites occurs in two hosts - permanent and transitional one (1, 2, $13,14)$. The permanent host in normal conditions is a pig and in accidental conditions is a man, who gets infected by eating raw or heat, or any other inadequately treated pork meat, when the larva in the intestines develops into a taenia. Then the man contracts taeniasis (pork tapeworm). The transitional host is a pig, and sometimes man. Man is infected via contaminated food and water or via "dirty hands", when he directly ingests the eggs of taenia. Then the man contracts cysticercosis.

The clinical picture of cysticercosis depends on the localisation and number of cysticerci, as well as on the host's immune response to the presence of measles $(1-6,8,9,12,13)$.

Dissemination of cysticerci into the central nervous system (CNS) results in neurocysticercosis with varieties - subarachnoid, intraventricular and spinal neurocysticercosis. In neurocysticercosis, the cysticerci are in the brain parenchyma, usually localised at the border of gray and white brain matter. It manifests by headaches, seizures, psychosomatic disorders, ataxia, involuntary movements, sensory deficits, etc. The occurrence of mental and intellectual disorders are the signs of damage to the parenchyma, hydrocephalus, meningitis and/or arachnoiditis.

Dissemination of cysticerci in any other tissue or organ leads to extraneural cysticercosis with clinical varieties - ocular, subcutaneous, muscular and cardiac.

In ocular cysticercosis, measles can be localised in any part of the eye $(1,4,8-10)$. Most frequently they are in the vitreous body, subretinaly and subconjunctivaly, rarely in the orbital tissue, and the rarest in the optic nerve. Clinical manifestations are eye pain, eye redness, exophthalmus, cataract, iris atrophy and blindness.

Subcutaneous cysticercosis manifests with visible, small, mobile and painful nodules, usually in the arms and chest, which are, in the beginning of the illness, larger and softer, accompanied by the signs of inflammation, and later, after a few years, gradually disappear, as a sign of extinction of the measles.

Muscular cysticercosis manifests with muscle pain and spasms, usually in the arms and thighs.

Cardiac cysticercosis is in the majority of patients asymptomatic or with the signs of arrhythmia, tachycardia, dyspnoea, syncope and so on.

Radiographic images of cysticircosis are pathognomonic, sometimes being even sufficient for the diagnosis $(5,6,9,11,12,14)$. Of importance in that regard are standard radiography (analog or digital), computed tomography (CT), magnetic resonance imaging (MRI) and other radiological modalities $(5,6,9,11,12,14)$.

On a standard radiograph of the heart and lungs, abdomen, urinary tract and extremities, a cysticercus becomes visible when in the shells of the measles calcium salts are being deposited, which is a sign of its death. It is very important to examine the patient diascopically as a whole, the entire body, in order to discover calcified parasites. On standard radiographs, the parasites are visualized as round, ovoid or similar shadows, with calcium intensity, rarely solitary, more often multiple, with approximate diameter of $10 \times 3 \mathrm{~mm}$, with sharp edges, intense circumferentially, which lie longitudinally to the muscle bundles, parallel to the course of muscle fibers, usually in the upper and lower legs, upper extremities, neck, or in the muscles of the entire body.

Cysticercosis of the human brain is diagnosed with certainty on CT and MRI. The picture obtained by neuroimaging depends on the localisation, number and development stage of the larvae of parasites, i.e. whether they are alive or dead cysticerci.

Live cysticerci on computed tomograms of the brain appear as solitary (rarely) or multiple (more often), oval or round, sharply delineated, hypodense cystic formations, with the diameter of up to $15 \mathrm{~mm}$. They are most commonly encountered in the cortex, rarely in the basal cisterns, more rarely in the brain ventricles, where cysticerci swim in the cerebrospinal fluid or are attached to the ventricle wall, and the rarest are subarachnoid. Within individual cysts, scolexes with soft tissue formations in hypodense fluid of the cyst can be visualised. After the i.v. applications of iodine contrast they do not change the density of the contents $(5,11,14)$. Sometimes a perifocal edema can be found around a cysticercus, with mild, expansionary effects, which is best visualized on MRI. Calcified cysticerci in the brain tissue appear on CT as multiple, rarely solitary, round calcifications, with up to $10 \mathrm{~mm}$ in diame-ter. Often with these described CT changes of cysticercosis in the brain, hydrocephalus is found.

The MRI findings of cysticercosis in the brain do not differ from CT findings; however, cysticerci are here diagnosed as hyposignal changes with strong perifocal edema with a cysticercus beginning to degenerate.

The aim of the study was to present the radiological-clinical aspects of cysticercosis (cysticercosis), while the material of the study consisted of radiographs from the years old radiographic materials of dr sc. Rade R. Babić, from which the radiographs of a female patient suffering from cysticercosis were selected and processed, brought as a refugee to her friend in Niš after the hurricane of war in Bosnia and Herzegovina, via a concentration camp, and with the mediation of UNPROFOR $(6,15)$. 


\section{Results}

Our work is illustrated through the radiological findings of a female patient suffering from cysticercosis, hospitalized at the Clinic for Pulmonary Diseases and Tuberculosis - Knez Selo due to changes in the lungs (medical history 841/95). Subjective symptoms are: shortness of breath, fatigue, pain in the abdomen, spine and ribs, exhaustion, weight loss. She denies past medical diseases and surgeries. Objectively, on admission, she gives the impression of a seriously ill patient. She is cachectic, dyspnoeic, afebrile. On physical examination, percutaneous dullness right from the middle of the shoulder blades to the base of the lungs was found. On auscultation, in the area of dullness, there is depressed respiration, progressing to silence at the base of the lung. Physical findings of the heart are normal. In addition to epigastric tenderness, light enlargement of the liver, varices and the edema of tibias and skin changes (moving, painless subcutaneous tumerfacts, which raise the skin, a couple of centimetres in size) physical examination does not show other pathological changes. Ophthalmologists diagnose an initial cataract of the lens on both sides.

On the standard analog radiograph of the lungs and heart in the middle and lower right lung field, the presence of a massive homogeneous shadow of soft tissue intensity can be seen, which displaces the mediastinum to the left. Cranially, the shadow is clearly limited, convex upwards. In the projections of other parts of the lungs, shadows of calcium density, ovoid and oval in shape, measuring about 5-6 mm, are present. Through careful interpretation, the radiographic shadows of calcium density are diagnosed also outside the lungs, in the soft tissue of the thoracic wall, even subcutaneously, and some are positioned in parallel to the muscle of the upper arm.

On subsequent radiographs of the upper arms and thighs (Figure 1), numerous spindleshaped and round shadows of calcium intensity are found in the soft tissues and muscles, with a diameter of up to $10 \mathrm{~mm}$, fusiform in appearance, placed with a longer axis parallel to the course of the muscle fibers, which corresponds to calcified cysticerci.

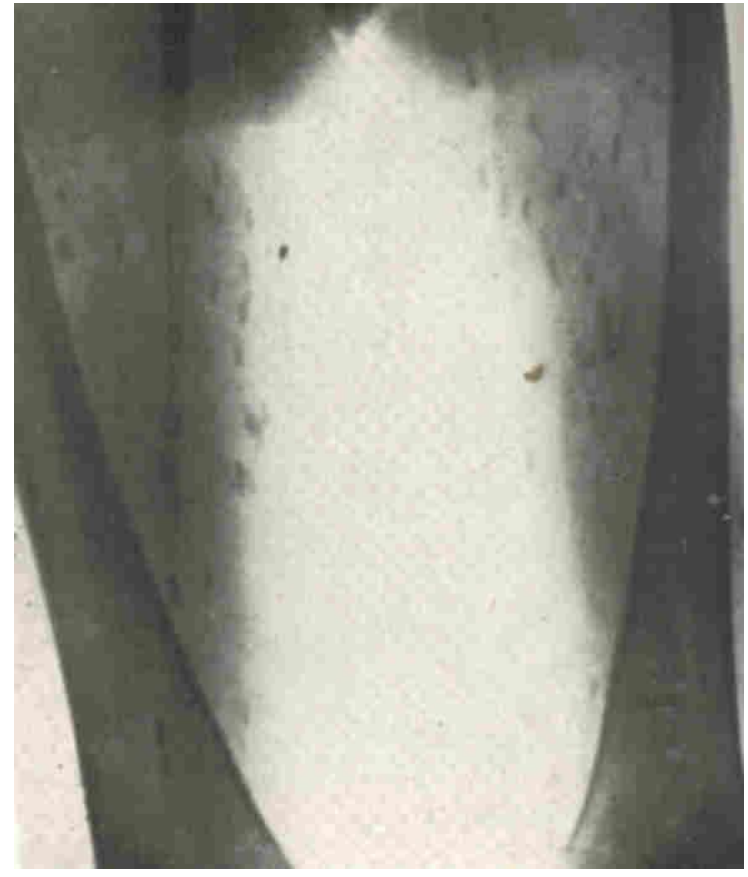

Figure 1. Cysticercosis

\section{Discussion and conclusion}

Human cysticercosis in our community is an extremely rare disease. Human suffering, exile, decline in the standard of living, migration of population because of war and poor economic conditions and other things have provided an opportunity to encounter, among other diseases, cysticercosis as well. Through decades of radiological work we have diagnosed cysticercosis by accident, through the radiological examination of the lungs and heart in one female patient, brought as a refugee to her friend in Niš after the hurricane of war in Bosnia and Herzegovina, via a concentration camp, and with the mediation of UNPROFOR. The radiological image of cysticercosis in our female patient was pathognomonic. Serological reaction at that time, during the war and unrest, due to the sanctions and material reasons was never done.

The diagnosis of cysticercosis is made on the basis of clinical picture, radiological images, serological results and epidemiological data.

References

1. Stevanović M: Kliničke karakteristike i dijagnoza cisticerkoze. Diplomski rad. Medicinski fakultet. Univerzitet u Nišu. Niš. 2015.
2. Otašević $S$, Miladinović Tasić $N$, Tasić A: Medicinska parazitologija sa CD-om, udžbenik. Medicinski fakultet u Nišu\&Galaksija. Niš, 2011: 127-132. 
3. Zlatanović G, Veselinović D, Jovanović P: Oftalmologija. Galaksija - Niš. Niš. 2011.

4. Milisavljević S: Kliničke karakteristike i dijagnoza cisticerkoze. Diplomski rad. Medicinski fakultet. Univerzitet u Nišu. Niš. 2010.

5. Babić RR, Stanković-Babić G: Rendgenološkooftalmološka slika bolesnog oka. Acta Ophthalmologica 2007; 33: 17-22.

6. Kanski JJ: Clinical ophthalmology. Butterworth. Heinemann .Edinburg. London. New York. Philadelphia. St Louis. Sydney. Toronto. 2003.

7. Stojšić M, Nastasijević I: Zanatska prerada mesa, bolesti zoonoze i sistem kontrole bezbednosti hrane. SD Public. Beograd. 2004.

8. Milatović S: Kompjuterizovana tomografija neurokarnijuma. Punta - Niš. Niš. 2001.

9. Babić RR: Neželjene pojave od kontratsnih sredstva pri urografiji sa predlogom mera za smanjenje rizika. Doktorska disertacija. Beograd: Univerzitet; 1998.

10. Babić RR, Babić MR: Rendgenski aspekti cističnih formi larvi izvesnih tenija. RAS 1998; 2: 225-229.

11. Babić MR, Babić RR, Živkovć $D$, Golubović $S$, Stanković-Babić G, Antanasijević S, Ignjatović R: Rendgenska slika cisticerkoze - povodom nalaza $u$ našeg bolesnika. Acta medica Medianae 1996; 4: 97-105.

12. Ruckij VA, Mihajlov N: Rentgeno-diagnostičeskij atlas. Višejšaja Škola. Minsk, 1987.

13. Karakašević B: Mikrobiologija sa parazitologijom. Medicinska knjiga. Beograd-Zagreb. 1980.

14. Cysticercosis. http://en.wikipedia.org (poslednje otvaranje 24 mart 2015)

15. Babić RR: Filmoteka - rendgenogrami stečeni višegodišnim radom u struci od 1991-2015.g.

\title{
Revijalni rad
}

UDC: 616.993-073.7

doi: $10.5633 / \mathrm{amm} .2017 .0414$

\section{RENDGENOLOŠKO-KLINIČKI ASPEKTI CISTICERKOZE}

\author{
Rade R. Babić1 , Gordana Stanković-Babić2 ${ }^{24}$, Marko Ristić ${ }^{3}$
}

\author{
${ }^{1}$ Centar za radiologiju, Klinički centar Niš, Niš, Srbija \\ ${ }^{2}$ Klinika za očne bolesti, Klinički centar Niš, Srbija \\ ${ }^{3}$ Veterinarski zavod Subotica,Subotica, Srbija \\ ${ }^{4}$ Univerzitet u Nišu, Medicinski fakultet, Niš, Srbija \\ Kontakt: Rade R. Babić \\ Bul. dr Zorana Đinđića br. 48, 18000 Niš, Srbija \\ E-mail: gordanasb@mts.rs
}

Cisticerkoza (cysticercosis) predstavlja oboljenje uzrokovano cisticerkozom celuloze (Cysticercus cellulosae), larvom svinjske pantljičare (Taenia solium), kada je čovek prelazni domaćin. Cilj rada bio je prikaz rendgensko-kliničkih aspekata cisticerkoze (cysticercosis). U radu su ilustrovani rendgenološki nalazi i slike cisticerkoze kod jedne bolesnice koju je vihor rata u Bosni i Hercegovini, preko koncentracionog logora, uz posredovanje UNPROFOR-a, kao izbeglicu doveo u Niš. Autori zaključuju da je rendgenološla slika cisticerkoze tipična, da su radiološke metode pregleda relevantne u dijagnostici cisticerkoze, a da se dijagnoza sa sigurnošću postavlja na osnovu kliničke slike, radiološke slike, seroloških rezultata i epidemioloških podataka. Acta Medica Medianae 2017;56(4):90-93.

Ključne reči: cisticerkoza, radiologija, mikrobiologija, veterina 